\title{
EFL Students' Perspective on the Usefulness of ICT based Learning in Indonesian Higher Education
}

\author{
Muhammad Basri \\ muhammadbasri@unm.ac.id \\ Muhammad Azwar Paramma \\ azwarparamma@gmail.com
}

Universitas Negeri Makassar

\begin{abstract}
The study explores the perception of the EFL students in English Language Teaching through ICT based learning at Universitas Negeri Makassar. It employs a descriptive study using purposive sampling techniques by taking 57 respondents from university students. The online questionnaire used to collect data on the perception of students on the ICT based Learning of English Language Teaching. The method of descriptive in terms of percentage has been used for data processing, and the deduction method has been used to analyze and interpret data. The result of this study indicates the positive perception those university students hold on the use of Learning Management System in English Language Teaching. Further study can refer to this Acceptance Model in determining a suitable ICT integrated learning program between the reality and user expectations of the program used.
\end{abstract}

Keyword : ICT, Technology Acceptance

\section{INTRODUCTION}

Over centuries, education occupies a vital role during the teaching and learning process and the creation of knowledge in human history. As the process of teaching and learning became formal and systematic in the times and technologies, the need for effective methods and strategies to raise the quality of education have been concerned with the issue of increasing the efficiency of the learning experience. The process of developing an educational technology system involving curriculum and pedagogy, infrastructure, capacity building, language, and content, and financing, which are strictly related to each other (Aktaruzzaman, Huq Shamim, \& Clement, 2011; Halimah \& Paramma, 2019; Paramma, 2018).

The phenomenon of the use of information and communication technologies (ICT) is now overgrowing in Indonesia. Based on the statistical data of internet users provided by Internet World Stats (2018), the growth rate of internet users in 
Indonesia from 2000 to 2017 showed a very significant increase, which reached 143.26 million users, which initially only 2 million people users. This growth rate means the percentage of internet users in the recent 17 years is about 7.1\%. Although the penetration of internet users in Indonesia, which estimates the population of 2017 around $266,794,980$ people, has reached $63.7 \%$, this rapid growth indicates the use of the Internet is a universal medium for Indonesians seeking information. Such data urges educators to immediately consider instructional teaching models that utilize information and communication technologies. The data does not mean removing the lecturer's role in front of the classroom, books, and whiteboards, but the combination, or hybrid, between conventional and virtual means, needs to be developed and implemented following our educational situation (Syam, Basri, Abduh, \& Patak, 2019).

The information and communication technologies (ICT) integration in the classroom, well known as Educational Technology, brings new insights to enhance the quality of education, especially in higher education. This insight triggers the rapid diffusion and adoption throughout developed societies. However, ICT has not been comprehensively applied in the daily social practice; specifically, in the university environment, it tends to be slower to adjust lesson plans with the need for the use of technology to adjust the development of education (Livingstone, 2012).

Furthermore, there are still constraints in the implementation of ICT in teaching and learning activities. While the number of studies provided shows the ease of use, extensive resources, and effectiveness in the application, Đorđević (2017) point out, University Teachers lack the objective possibilities for a broader application of ICT based teaching and learning even though they are familiar with both the role and scope of ICT. It suggests useful changes in the entire system of education for the identified problems. It prompts the need for further research to investigate the motivation among university teachers for the application of Information and Communication Technology-based learning, both in their study and their everyday work. It also suggests a structured implementation of training for university teachers is of utter importance to help them apply ICT based learning in their research; the computer is the most important. Moreover, a priority of all institutions should be to provide university teachers with adequate tools, and free access to all available online sources is into consideration in changes in the entire system of education. In brief, the functional changes are needed at all levels of education to provide teachers with a better and more modern environment in learning to apply ICT based learning both in teaching and scientific research (Basri \& Patak, 2015; Hudriati, Rusdiah, Patak, \& Basri, 2018).

The findings above show the need for the development of conventional learning methods into learning that integrated with online learning, such as ICT based learning or ICT based learning. A group of studies demonstrates the need for online learning integration into the learning process to maximize student learning experiences (Australian National Training Authority, 2003; Garcia, 2012; D. Randy Garrison \& Kanuka, 2004; D R Garrison \& Vaughan, 2008; Hartley, 
Woods, \& Pill, 2005), although there is still research showing constraints in the implementation process of ICT based learning (Đorđević, 2017).

This research is intended to contribute to filling this gap by examining the ICT based learning of the EFL students of the English Education Program. It deals with the implementation of ICT based learning in the English Department at Indonesian University Level.

\section{LITERATURE OF REVIEW}

\section{ICT in English Language Teaching (ELT)}

Katzman (1974) had an earlier study on Information and Communications Technology by exploring the impact of communication technology for prospects and promises. Further, it showed place possibilities of this information and communications technology as new media and new ways of using the available resource. It conceived new communication techniques and technologies are introduced as the painless solution to solve major social, economic, and educational problems. It recommended going into deep patterns to formulate effective policies. It concerned the relationships between new communication techniques and the distribution of information in society.

Recently, the studies of Information and Communications Technology in English Language Teaching had been the focus of some researchers (Arham \& Akrab, 2018; Hu \& McGrath, 2011; Matukhin \& Zhitkova, 2015; Rahman Sidek $\&$ Md.Yunus, 2012).

$\mathrm{Hu} \&$ McGrath (2011) investigated the innovation in higher education regarding the teachers' readiness to integrate ICT in English Language Teaching. They focused on the teachers' attitude towards ICT use in education and ICTrelated continuing professional development (CPD) policies and practices. They found that limited ICT skills and educational expertise were obstacles to implementing ICT in English Language Teaching. This finding involved several aspects of data collection, including classroom observation, teacher interviews, and focus groups discussion between teachers and students.

Further study on the learning innovation of ICT in English Language Teaching, Rahman Sidek \& Md.Yunus (2012) revealed the recommendation for ICT based learning improvement based on the students' recommendations. The study discussed the students' experiences in using Blogs as learning journals. It focused on exploring the students' experiences using blogs as leaning journals and its implementation as Learning Journals. The findings showed that students 
interested in the use of computer tools in their learning experience, and most of them suggested using blogging for further lessons.

Matukhin \& Zhitkova (2015) further examined the effectiveness of Information and Communication Technology in English Language Teaching. Their study explored the implementation of Information and Communication Technology in Higher Professional Education focused on the English Language Teaching students' learning outcomes. It aimed to enhance the efficiency of the learning process employing conventional technological means of instruction. Data questionnaire and observation as an experimental study performed to explores the students' readiness and competence in this study. It provided the processing and analysis of experimental data to identify the level of the students' level of information competence by analyzed students' psychological readiness to handle information and communication technologies.

To some extent, the numbers of previous studies are related to this study. However, some aspects are still different. This study investigates the students' perspective on the use of Information and Communication Technology in learning practices. Moreover, it also concerns the usefulness of Information and Communication Technology to the English Language Teaching students. The similar issues on the student's experiences on the implementation of Information and Communication Technology in the classroom practices presented by Matukhin \& Zhitkova (2015) and Rahman Sidek \& Md.Yunus (2012). In this study, the issue covers not only the students' perspectives and practices about ICT but also explores their experience during the implementation of material development and accessibility of ELT materials provide in the designed learning management system. Other previous studies $\mathrm{Hu} \&$ McGrath (2011) investigated Information and Communication Technology to innovation and educational development issues. While $\mathrm{Hu} \&$ McGrath (2011) examined the obstacles faced by the teachers in implementing ICT in English Language Teaching, this study covered the students' perception of Information and Communication Technology in their learning practices. In other words, this study is similar to some extent with the previous studies mentioned before, but different in some aspects of Information and Communication Technology.

\section{Technology Acceptance Model}

In relevance to the perspective and attitudes towards Information and Communication Technology-based learning, (F D Davis, 1985) introduced the Technology Acceptance Model to measure the user acceptance of computer-based information systems. According to the Technology Acceptance Model, there are four relational indicators with two major beliefs affecting the acceptance of 
informatics innovations; they are perceived usefulness (PU) and perceived ease of use (PEOU). Perceived usefulness (PU) refers to measure in which an individual believes that using a particular system enhance users job performance, while perceived ease of use (PEOU) refers to measure in which users belief on a particular system would be free of workload and thinking effort. Further indicator Technology Acceptance Model is attitudes toward technology and actual technology to use. Attitude toward technology refers to evaluate the effect in which individuals associated with using the target system in users' performance, while Actual Technology to Use (ATU) refers to an individual's actual direct usage of the given technology in the context of users performance. Thus, it is a repeated, multiple-act behavioral criterion that is specific concerning target (specified system), action (actual direct usage) and context (in person's job), and non-specific concerning the period.

\section{METHOD}

The study was a descriptive survey using purposive sampling to investigate the EFL students' perspective on the usefulness of ICT based learning in their learning practices. The method of descriptive in terms of percentage has been used for data processing, and the deduction method has been used to analyze and interpret data.

The participants involved the fifth-year students of the English Education Program at Universitas Negeri Makassar. The targeted participants in the present study were fifty-five students, which consist of two-class groups. ICT based learning model applied in this study was a combination of online classes and faceto-face meetings. The online class applied a Learning Management System called Moodle, which is a campus learning facility. By using this Learning Management System, the students could easily access the lecture material online, evaluate lecture material, reflect the result of discussion at face-to-face meetings, and submit weekly assignments and final semester assignments.

The instrument of this study consists of an online questionnaire using SurveyMonkey, which generates analytical data based on the participants' responses. It used to answer the students' perception using the ICT based learning of English Language Teaching. The online questionnaire adapted the Technology Acceptance Model (TAM) constructed by Davis (1985) with some adjustment for classroom activities in English Language Teaching based on Wiyaka, Mujiyanto, \& Rukmini (2018). The questionnaire using a 5-point Likert response scale where 5: Strongly agree, 4: Agree, 3: Neutral, 2: Disagree, and 1: Strongly Disagree. The model construct of the items can be seen in Table 1 below. 


\section{Section I}

I feel that using ICT based learning would be easy for me

\section{PEU 1}

I feel that it would be easy to become skillful at using ICT

PEU2

based learning

I would find ICT based learning to be flexible to interact

PEU3 with

Learning to operate ICT based learning would be easy for me PEU4

It would be easy for me to get ICT based learning to do what PEU5 I want to do

I feel that my ability to determine ICT based learning ease of PEU6 use is limited by my lack of experience

\section{Section II}

Usefulness (PU)

Using ICT based learning in my English Language Teaching

PU1

course would enable me to accomplish tasks more quickly

Using ICT based learning would improve my English

PU2

Language Teaching course performance

Using ICT based learning in my English Language Teaching

PU3

course would increase my productivity

Using ICT based learning would enhance my effectiveness

PU4

on the English Language Teaching course

Using ICT based learning would make it easier to do my

PU5

English Language Teaching course

I would find ICT based learning useful in my English

PU6

Language Teaching course

\section{Section III}




\section{I believe it is a good idea to use an ICT based learning on ATU1 \\ English Language Teaching course \\ I like the idea of using an ICT based learning on English ATU2 \\ Language Teaching course \\ Using an ICT based learning on English Language Teaching ATU3 course is a positive idea}

\section{Section IV}

I plan to use an ICT based learning in the future

\section{BIU1}

Assuming that I have access to ICT based learning, I intend BIU2 to use it

Note: ICT based learning=Language Management System, a trademark of commercial Moodle in UNM

\section{RESULT AND DISCUSSIONS}

The findings showed that the overall mean score on the perception of ICT based learning usage in the English Language Teaching course was 4.18 (SD = 0.653). Such overall mean score and standard deviation described in the table demonstrate that participants in this study represent a positive perception towards the use of ICT based learning in English Language Teaching course. Furthermore, the overall data displayed in Table 4 shows that most participants gave a very positive response to the ease of use of ICT based learning.

\begin{tabular}{llccc}
\hline Item & Mean & $\begin{array}{c}\text { Std. } \\
\text { Dev. No }\end{array}$ \\
\hline $\begin{array}{l}\text { Perceived Ease of Use } \\
1 \quad \begin{array}{l}\text { I feel that using an eLearning would be easy for } \\
\text { me }\end{array}\end{array}$ & 4.58 & 0.529 & 55 \\
$2 \quad \begin{array}{l}\text { I feel that it would be easy to become skillful at } \\
\text { using eLearning }\end{array}$ & 4.44 & 0.707 & 55
\end{tabular}


111 ELT Worldwide Vol. 6 No. 2 (2019)

Basri, Azwar Paramma : Students' Perspective on the Usefulness ...

3 I would find eLearning to be flexible to interact

$4.11 \quad 0.730$

55 with

4 Learning to operate eLearning would be easy for me

5 It would be easy for me to get eLearning to do

$4.07 \quad 0.850 \quad 55$ what I want to do

6 I feel that my ability to determine eLearning ease of use is limited by my lack of experience

\section{Usefulness}

7 Using eLearning in my English Language $4.2 \quad 0.553 \quad 55$ Teaching course would enable me to accomplish tasks more quickly

8 Using eLearning would improve my English $4.07 \quad 0.657 \quad 55$ Language Teaching course performance

9 Using eLearning in my English Language $\begin{array}{lll}4.09 & 0.611 \quad 55\end{array}$ Teaching course would increase my productivity

10 Using eLearning would enhance my effectiveness $\begin{array}{lll}4.09 & 0.548 \quad 55\end{array}$ on the English Language Teaching course

11 Using eLearning would make it easier to do my English Language Teaching course

12 I would find eLearning useful in my English Language Teaching course

\section{Attitude toward Usage}

13 I believe it is a good idea to use an eLearning on $\begin{array}{lll}4.29 & 0.593 \quad 55\end{array}$ English Language Teaching course

14 I like the idea of using an eLearning on English Language Teaching course

15 Using an eLearning on English Language $\begin{array}{lll}4.33 & 0.574 \quad 55\end{array}$ Teaching course is a positive idea 


\section{Behavioral Intention to Use}

16 I plan to use an eLearning in the future

17 Assuming that I have access to an eLearning, I intend to use it
$4.05 \quad 0.585 \quad 55$

$3.87 \quad 0.541 \quad 55$
Overall
4.18
0.653

\section{Table 1. Students' perception of ICT based learning of English Language Teaching}

Further findings of the survey are presented based on each item in the questionnaire. Since there are four categories of the questions based on the Technology Acceptance Model by Davis (1985), the collected data will be presented under the heading of the group in the following section.

\section{Perceived Ease of Use}

Perceived Ease of Use (PEOU) is the extent to which prospective users expect the target system to be free of effort (F. Davis, 1989). In this study, it refers to the degree that the students believe that the use of ICT based learning requires a relatively low workload and thinking effort. It implies that the tool of ICT based learning, which is applied, should make the learning simple. The following figure describes the students' responses.

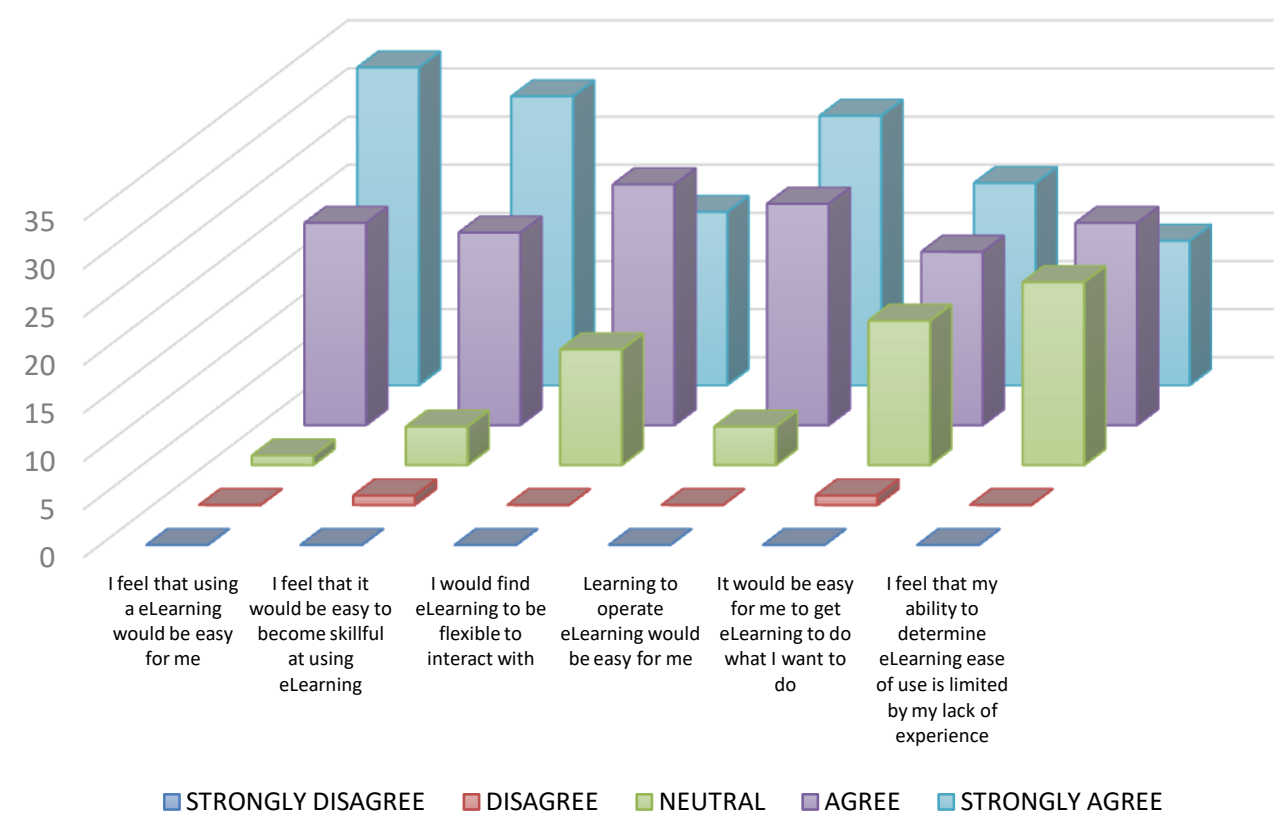

Figure 1. Perceived Ease of Use (PEOU) 
113 ELT Worldwide Vol. 6 No. 2 (2019)

Basri, Azwar Paramma : Students'Perspective on the Usefulness ...

Regarding the figure above, we can infer that ICT based learning seems easy for students to implement. When combined, almost all of the students perceived that the courseware is easy to use $(98.2 \%, \mathrm{n}=54, \mathrm{M}=4.58, \mathrm{SD}=$ $.529)$.

Practicality and simplicity of the tool or the software used in the learning experience are of paramount consideration for the students. It is understandable since students usually avoid programs, which are difficult to operate. Any particular program is preferred when it would be free of effort. The software program must be free from difficulty or great effort. The aim is limited resources that a person can allocate to various activities for which users are responsible (Radner \& Rothschild, 1975). Further, users believe that the application, which is provided by the university, is more comfortable to use than the other is.

\section{Perceived Usefulness}

According to (F. Davis, 1989), Perceived Usefulness (PU) is the subjective probability of prospective users using a particular application system that will improve their work performance in an organizational context. In this study, PU refers to degree that ELT students believe that using ICT based learning would enhance their English Language Teaching performance. The following figure describes the students' perceived usefulness. 


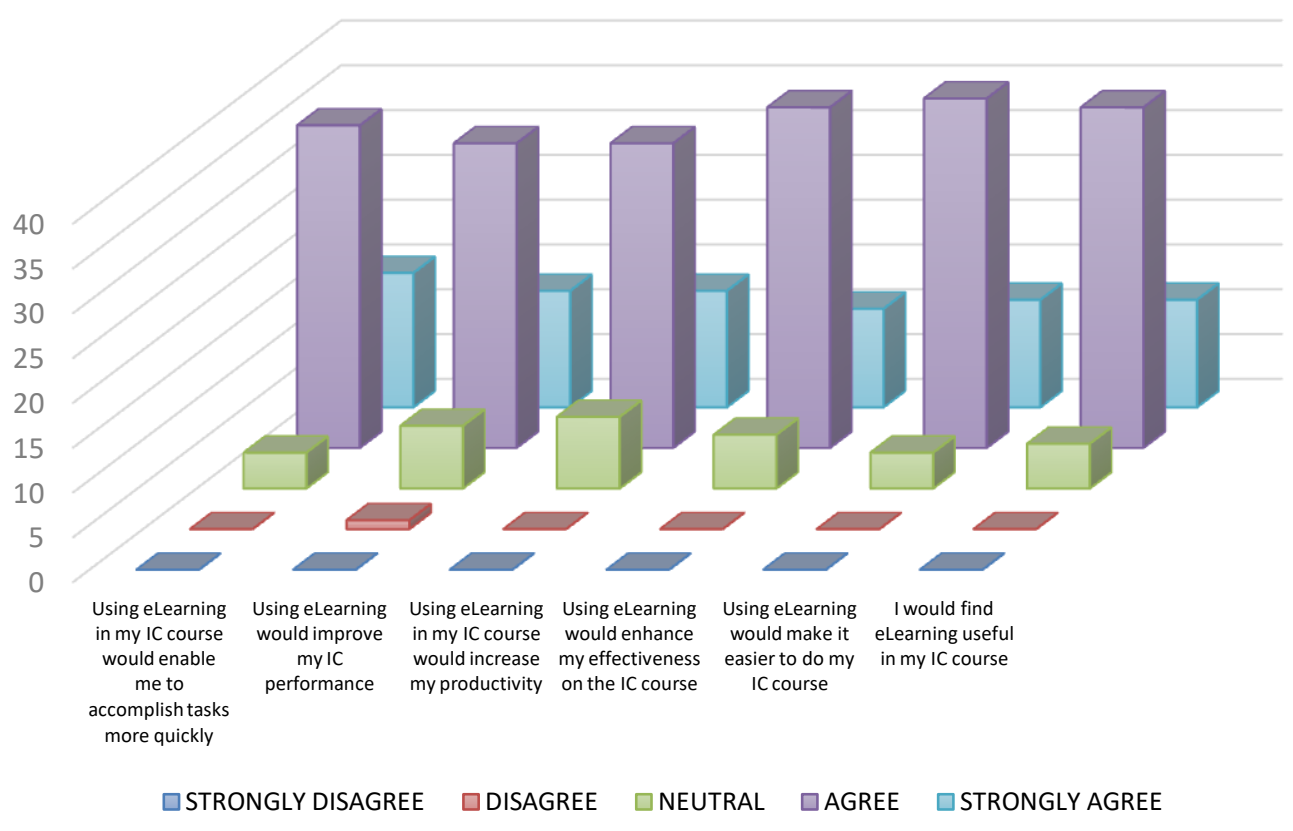

Figure 2. Perceived Usefulness (PU)

Based on the figure above, we can infer that using ICT based learning in the English Language Teaching course can be useful to enhance students' English Language Teaching performance. From the whole items of students' perceived usefulness, almost all of the students agreed that using ICT based learning in English Language Teaching becomes useful for their performance (89.4\%).

Again, perceived usefulness here is defined as the degree to which a student believes that using ICT based learning would enhance their learning performance. It is clear from the figure that almost all the students perceived that ICT based learning is useful to accomplish their English Language Teaching course. From six items to be displayed in measuring students' recognized usefulness, only $10.3 \%$ of students thought that ICT based learning is not useful to support the learning process in the English Language Teaching course. It must be an essential warning to the developer of learning material in the program to seek the causes of such a perception. A tool will be used when it brings about improvement in the learning performance. In other words, people will use a device when it is useful for their learning experiences. A program has high-perceived usefulness when the user believes in the existence of a positive use-performance relationship (Ajzen \& Fishbein,

2000). 


\section{Attitude towards Usage}

Attitude towards Usage (ATU) represents individuals' evaluative feelings (positive or negative) when performing a particular behavior (Ajzen \& Fishbein, 2000). ATU will determine the intention to use a specific program or learning tool. The students' attitude towards ICT based learning can be seen in the following figure.

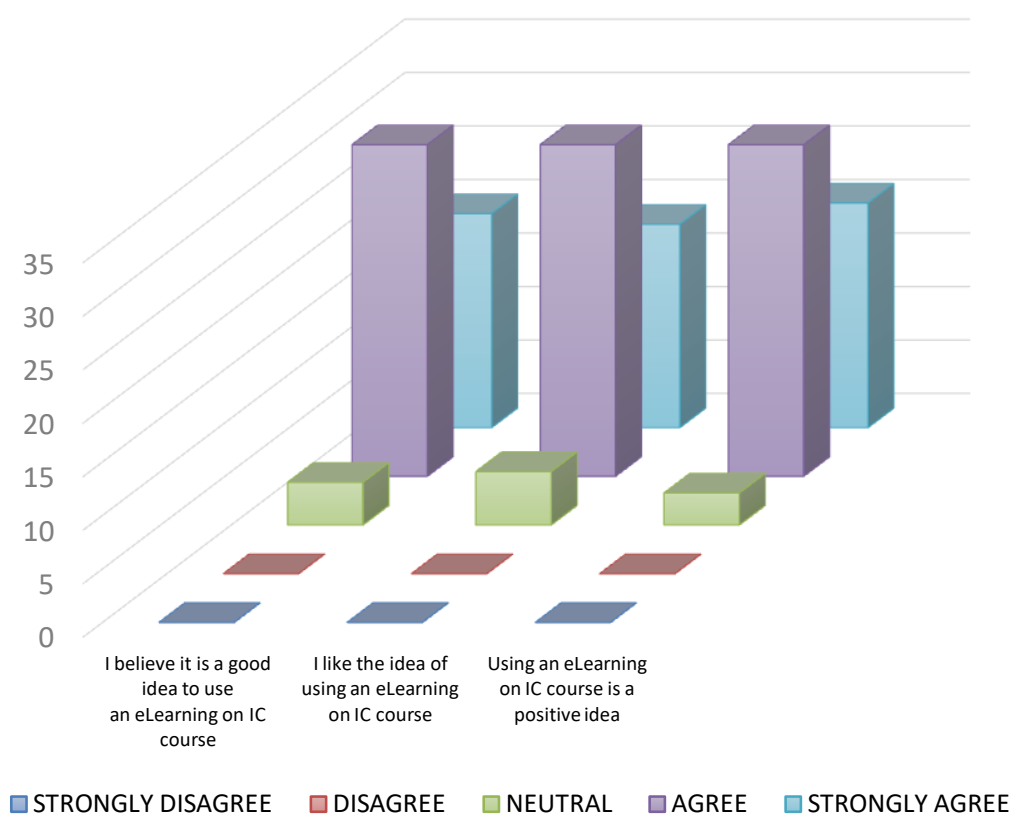

Figure 3. Students' Attitude towards Usage

Based on data, we can be identified that using ICT based learning in the English Language Teaching course is a good idea. From the comprehensive data on students' attitude towards the usage of ICT based learning in English Language Teaching course, almost all students admitted that ICT based learning in English Language Teaching is a good idea (92.8\%) while only $7.3 \%$ do not have an idea about the ICT based learning.

It shows how the suitability of user expectations is following the program provided for their learning experience. An application should ideally present a good and positive impression on the users. When more than 20 percent of the users complain about the product, there must be direct review from the designer to improve the product. This attitude has been identified as a factor that guides future 
behavior and as an intentional cause that ultimately leads to a particular action (Wiyaka et al., 2018).

\section{Users' Behavioral Intention to Use the Program}

Behavioral Intention to Use (BIU) is defined as the actual use of a given program and therefore determines technology acceptance. The BIU is similar to a drive to apply alternatively, use the program. The following figure represents the students' intention to use ICT based learning.

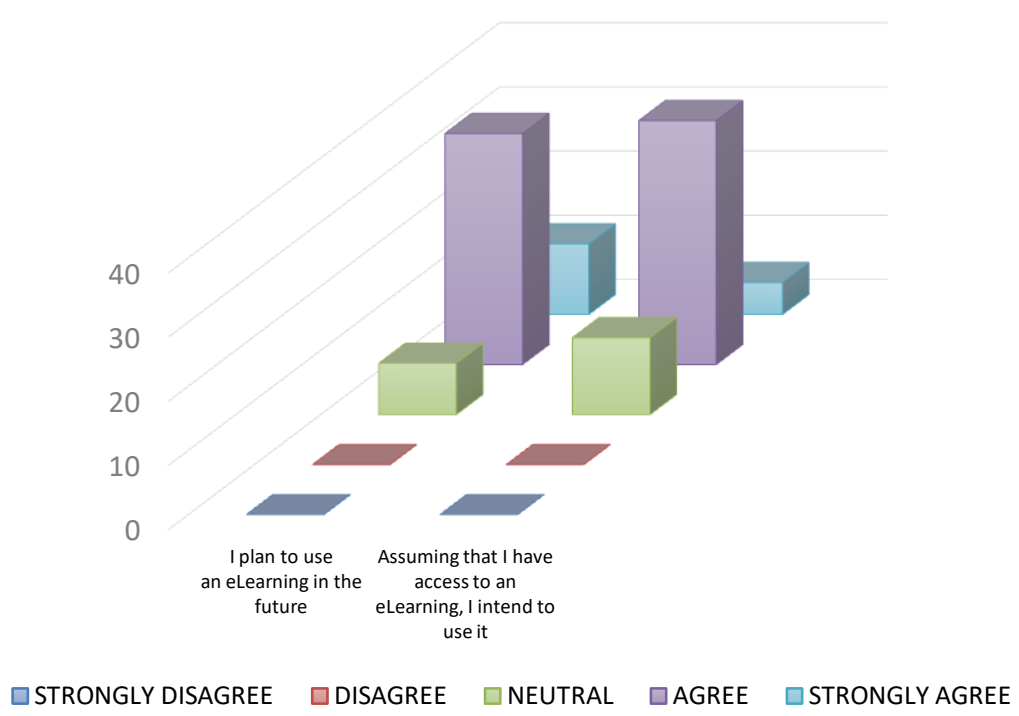

Figure 4. Users' Behavioral Intention to Use (BIU) the Program

According to the Figure, we can infer that ICT based learning can be a feasible application to be recommended in supporting the learning classroom process in the future. From the comprehensive data on users' behavioral intention to use the program, almost all students plan to use ICT based learning (81.8\%), and only $18.2 \%$ of students who do not have an idea about the plan to use ICT based learning in the future.

It has been identified that there are factors that guide future intentions. One's attitude towards the program will ultimately lead to a particular behavior. According to the model, a user's intention is affected by the attitude towards the system. A user's perceptions of the usefulness and ease-of-use brought impact to the user's intention to use (BIU) to the system (Fred D. Davis, Bagozzi, \& Warshaw, 1989). 


\section{CONCLUSIONS, IMPLICATION, AND SUGGESTIONS}

The university students hold a positive perception on the use of ICT in English Language Teaching. Despite the constraint associated during the process of its implementation, students also provide a positive response from their willingness to complete the tasks given in the Moodle. Depart from the findings and discussions discussed previously; it presents concluded points of the study.

The result shows that university students hold positive perceptions towards the use of ICT based learning in the English Language Teaching course. With this finding, students maintain that ICT based learning makes their learning easier and useful for their English Language Teaching course. In support of that easiness, the ELT students thought that using integrating ICT and a face-to-face meeting is a good idea, and they plan to use it in the future. Although there were some inputs related to the adjustment of relevant material related to the English Language Teaching course that was running for the needs of the students as well as time adjustments between face-to-face meetings and online, majority of students remain positive towards the use of ICT based learning. Students also realize the importance of using technology to support their learning process later. Thus, students recommend for the university to maintain the use of ICT pedagogical training and motivation as the Learning Management System in the future learning and teaching process.

Future research is required to address how the other variables of the Technology Acceptance Model relate to ease of use, usefulness, attitude, and acceptance. It should be considered that perceived usefulness and ease of use are a subjective appraisal, which does not necessary objective views. Given that this study indicates that the user act according to their perceives about performance, further study can refer to this Acceptance Model in determining a suitable ICT integrated learning program between user expectations and the reality of the program used.

Further, the study was limited to the perception of students in the use of ICT in English Language Teaching. This limitation, therefore, goes to suggest that the study did not administer any treatment to students regarding the training and technical use of the Learning Management System. This study recommends that future research related to this subject would consider providing ICT pedagogical training for both lecturers and students. In this case, these studies will be able to ascertain the technical use of ICT based learning in teaching and learning. 


\section{REFERENCES}

Ajzen, I., \& Fishbein, M. (2000). Attitudes and the Attitude-Behavior Relation:

Reasoned and Automatic Processes. European Review of Social Psychology, 11(1), 1-33. Retrieved from http://www.tandfonline.com/doi/abs/10.1080/14792779943000116

Aktaruzzaman, M., Huq Shamim, R., \& Clement, C. K. (2011). Trends and Issues to integrate ICT in Teaching Learning for the Future World of Education. International Journal of Engineering \& Technology IJET-IJENS, 11(3), 114119. Retrieved from http://www.ijens.org/Vol 11 I 03/118603-0202 IJETIJENS.pdf

Arham, M., \& Akrab, A. H. (2018). Delving into content lecturers' teaching capability in content language integrated learning (CLIL) at an Indonesian university. Asian ESP Journal, 14(7), 68-89. Asian EFL Journal Press.

Australian National Training Authority. (2003). Blended learning: learning new skills in blending. Sydney: Australian National Training Authority.

Basri, M., \& Patak, A. A. (2015). Exploring Indonesian students' perception on Mendeley Reference Management Software in academic writing. 2015 2nd International Conference on Information Technology, Computer, and Electrical Engineering (ICITACEE), 8-13. Retrieved from http://ieeexplore.ieee.org/lpdocs/epic03/wrapper.htm?arnumber=7437761

Davis, F. (1989). Perceived usefulness, perceived ease of use, and user acceptance of information technology. MIS quarterly, 319-340. JSTOR.

Davis, F. D. (1985). A Technology Acceptance Model for Empirically Testing New End-user Information Systems: Theory and Results. Massachusetts Institute of Technology.

Davis, F. D., Bagozzi, R. P., \& Warshaw, P. R. (1989). User Acceptance of Computer Technology: A Comparison of Two Theoretical Models. Management Science, 35(8), 982-1003.

Đorđević, J. (2017). The Role and Scope of Information Communication Technologies in the Research of University Teachers in Serbia. TEME, 425438.

Garcia, H. F. (2012). Power of Communication,The: Skills to Build Trust, Inspire Loyalty, and Lead Effectively. Pearson Education. Retrieved from https://books.google.co.id/books?id=y3_xYKmAteAC 
Garrison, D. R., \& Kanuka, H. (2004). Blended learning: Uncovering its transformative potential in higher education. Internet and Higher Education, $7(2), 95-105$.

Garrison, D. R., \& Vaughan, N. D. (2008). Blended Learning in Higher Education: Framework, Principles, and Guidelines. Business professional collection. Wiley. Retrieved from https://books.google.co.id/books?id=2iaR5FOsoMcC

Halimah, S., \& Paramma, M. A. (2019). Attitudes and approaches of the EFL teachers on scientific approach in Indonesian school context. Asian EFL Journal, 23(3).

Hartley, P., Woods, A., \& Pill, M. (2005). Enhancing Teaching in Higher Education: New Approaches for Improving Student Learning. Routledge. Retrieved from https://books.google.co.id/books?id=z86EzHmIK-4C

Hu, Z., \& McGrath, I. (2011). Innovation in higher education in China: Are teachers ready to integrate ICT in English language teaching? Technology, Pedagogy and Education, 20(1), 41-59.

Hudriati, A., Rusdiah, R., Patak, A. A., \& Basri, M. (2018). Assessing Indonesian University Students' Preferences on Mendeley Reference Manager for Scientific Writing. International Journal on Advanced Science, Engineering and Information Technology, 8(5), 2211-2218.

Internet World Stats. (2018). Asia Internet Usage Stats Facebook and 2018 Population Statistics. Retrieved May 14, 2018, from https://www.internetworldstats.com/stats3.htm

Katzman, N. (1974). The Impact of Communication Technology: Promises and Prospects. Journal of Communication, 24(4), 47-58.

Livingstone, S. (2012). Critical reflections on the benefits of ICT in education. Oxford Review of Education, 38(1), 9-24.

Matukhin, D., \& Zhitkova, E. (2015). Implementing Blended Learning Technology in Higher Professional Education. Procedia - Social and Behavioral Sciences, 206(November), 183-188. Elsevier B.V. Retrieved from http://linkinghub.elsevier.com/retrieve/pii/S1877042815051848

Paramma, M. A. (2018). Teachers' Perspectives on Scientific Approach in Indonesian Educational Context. Asian EFL Journal, 20(5), 276-281. 
Radner, R., \& Rothschild, M. (1975). On the allocation of effort. Journal of Economic Theory, 10(3), 358-376.

Rahman Sidek, E. A., \& Md.Yunus, M. (2012). Students' Experiences on using Blog as Learning Journals. Procedia - Social and Behavioral Sciences, 67(November 2011), 135-143. Elsevier B.V. Retrieved from http://linkinghub.elsevier.com/retrieve/pii/S1877042812053001

Syam, H., Basri, M., Abduh, A., \& Patak, A. A. (2019). Hybrid e-Learning in Industrial Revolution 4 . 0 for Indonesia Higher Education. International Journal on Advanced Science, Engineering and Information Technology, 9(4), 1183-1189.

Wiyaka, Mujiyanto, J., \& Rukmini, D. (2018). Students' Perception on the Usefulness of ICT-Based Language Program. English Language Teaching, 11(2), 53. Retrieved from http://www.ccsenet.org/journal/index.php/elt/article/view/72882 